\begin{tabular}{l|l|l|l|l}
\hline Volume 1 & Issue 3 & December (2020) & DOI: 10.47540/ijsei.v1i3.75 & Page: $150-159$ \\
\hline
\end{tabular}

\title{
Floral Distribution, Diversity, and Ecology of Mangrove Forests in Mandaitivu and Arali, Sri Lanka
}

\author{
Ahalya Arulnayagam \\ College of Ocean Science and Technology Korea Maritime and Ocean Univ., Busan, Republic of Korea
}

Corresponding Author: Ahalya Arulnayagam; Email: ahalya.arulnayagam@gmail.com

\begin{tabular}{|c|c|}
\hline \multicolumn{2}{|c|}{ A R T I C LE I N F O } \\
\hline $\begin{array}{l}\text { Keywords } \\
\text { Diversity; }\end{array}$ & $\begin{array}{l}\text { Conservation; Distribu } \\
\text { Mangroves; Sri Lanka. }\end{array}$ \\
\hline Received & : 07 August 2020 \\
\hline Revised & : 03 December 2020 \\
\hline Accepted & : 05 December 2020 \\
\hline
\end{tabular}

A R T I C L E I N F O

A B S T R A C T

Mangroves in the northern parts of Sri Lanka have been understudied and often ignored by the ecologists due to several reasons. This paper contributes to the assessment of floristic diversity and community structure of mangrove forests in two sites in the Northern Province; Mandaitivu and Arali. Vegetation studies were undertaken with the use of $10 \mathrm{~m}$ wide belt transect laid across the water-land gradient, within which, 5-7 quadrats were placed for floral identification $\left(\mathrm{n}_{\text {Mandativu }}=\right.$ $\left.67, \mathrm{n}_{\text {Arali }}=44\right)$. Subsurface water samples $(\mathrm{n}=57)$ from the adjacent estuarine region were taken to assess environmental parameters. Ten true mangrove species of six families were identified altogether in both sites. Bruguiera cylindrica, Lumnitzera racemosa, Excoecaria agallocha and Avicennia marina showed higher niche width. Zonation exhibited Rhizophora in the fringing zone, Avicennia landward and the others in the mixed zone. Salinity in both areas was relatively high and showed a significantly positive correlation with mangrove abundance along with conductivity, tidal regime and $\mathrm{pH}$. Despite their important role in coastal dynamics, mangroves have been degraded due to anthropogenic activities, thus demanding actions for conservation in the future.

\section{INTRODUCTION}

Mangroves are a diversified group of predominantly tropical trees and shrubs growing in the marine intertidal zone where conditions are usually harsh, restrictive, and dynamic; such as rhythms of tides and seasons or long-term changes of climate and sea level. They are a dominant coastal vegetation system comprising chiefly angiosperms uniquely adapted to marine and estuarine tidal conditions; densely structured with closed canopies cloaking coastal margins and estuaries of equatorial, tropical, and subtropical regions around the world. As a group, they share several highly specialized and collectively well known for their morphological and physiological adaptations coping with salt, saturated soils, and regular tidal inundation, notably with specialized attributes (Duke, 1992). Mangroves define the landscape and participate directly or indirectly in the ecological processes that take place within the ecosystems (Jayatissa, Dahdouh-Guebas, \& Koedam, 2002).
Mangrove forests play a critical role in multiple ways within coastal landscapes, particularly where the communities depend on the richness of the aquatic resources their habitat supports (Rotich, Mwangi, \& Lawry, 2016). They provide a huge range of highly valuable ecosystem services, including support of biodiversity and fisheries, coastal protection, carbon sequestration, and nutrient processing (Sippo, Lovelock, Santos, Sanders, \& Maher, 2018). Despite their ecological and economic importance, mangroves have been destroyed from their motherlands i.e. wetlands due to rapid urban and industrial developments including constructions, agriculture, aquaculture, etc.

Sri Lankan mangroves are confined to a narrow strip since the tidal amplitude is low (less than $75 \mathrm{~cm}$ ) and they appear throughout the coastal belt more as a forest patch. There are ambiguities regarding the total mangrove extent of the country, due to lack of scientific data on the topic, yet the latest research reports an extent of about 15,670 ha 
widely distributed along the coastal districts (K.B. Ranawana, 2017) occupying the inter-tidal coastlines, mudflats and riverbanks in association with the brackish water margin thus establishing a link between the land and the ocean (Subasinghe, 2015).

The northern part of the island and their mangrove extent has been addressed rarely in literature, even though they have a wide range of mangrove forests reported by the Forest Department of Sri Lanka. According to available literature (Karunathilake, 2003); Jaffna peninsula holds the second largest mangrove forest on the island yet they are underreported in terms of diversity and abundance. The forest structure, the threedimensional arrangement of the individual trees, has a significant effect on the eco-systems services they provide. Analyzing the structural attributes of the existing mangroves is relevant to further studies based on their economic viability, carbon sequestration, forest plantation programs, and so on. Considering these facts, this study is undertaken to report the mangrove vegetation cover of two mangrove patches in the Jaffna peninsula, namely Mandaitivu and Arali, to assess the ecological status and analyze the mangrove structure about the environmental parameters. The results of this paper are expected to aid in the assessment of mangrove health and promoting replanting activities in the regions aforementioned.

\section{MATERIALS AND METHODS Study area}

Jaffna peninsula located in the northern-most part of Sri Lanka; extends from $9^{\circ} 49^{\prime} 17^{\prime \prime}$ to $9^{\circ} 28^{\prime}$ $13^{\prime \prime} \mathrm{N}$ latitude and $79^{\circ} 38^{\prime} 41^{\prime \prime}$ to $80^{\circ} 34^{\prime} 56^{\prime \prime} \mathrm{E}$ longitude; bounded by the sea on the west, north and east and by Jaffna lagoon in the south. The topography of Jaffna is almost flat with wideranging soil types including calcic red-yellow latesols, regosols, and solodized solonetz and solonchaks. It holds the second largest mangrove forest (2505 hectares) ever reported on the island (K.B. Ranawana, 2017). It belongs to the dry zone with uniformly high temperature all year round (range $26^{\circ} \mathrm{C}-33^{\circ} \mathrm{C}$ ) and an annual precipitation that ranges between $696 \mathrm{~mm}$ to $1125 \mathrm{~mm}$ (Gopalakrishnan, Kumar, \& Mikunthan, 2020). The highest elevation is 15.3 meters above sea level (masl), with a median being $2.72 \mathrm{~m}$ and the average tidal amplitude is between 0.115 and $0.17 \mathrm{~m}$. Of the several mangrove patches two of them, Mandaitivu and Arali were selected for this study purpose (Figure 1).

\section{Floristic survey}

Floristic survey and field sampling was carried out in December 2019, from the aforesaid areas. The stations were selected primarily based on the mangrove floral density and accessibility. Both sites selected were naturally available mangrove sites and both were observed to be human-impacted.

\section{Species composition and nomenclature}

The present study followed Pinto (1986) for species identification and nomenclature, which was derived from Tomlinson (1986) and Duke (1992).

\section{Structural analysis}

Fixed plot measurement was used for the characterization of the structural attributes of true mangroves based on the methods suggested by Snedaker, 1986. Mangrove floral vegetation was studied using $10 \mathrm{~m}$ wide belt transects in randomly selected points. The quadrat method was used for the structural analysis of true mangrove flora. Twelve transects in Mandaitivu and seven in Araliwere laid perpendicular to the High Tide Line (HTL); from the estuarine zone towards the landward margin. All the plots were installed more than $20 \mathrm{~m}$ away from the adjacent plot to avoid spatial autocorrelation. Within each transect, 5-7 quadrats $(5 \times 5 \mathrm{~m})$ were laid for the purpose of species identification $\left(\mathrm{n}_{\text {Mandaitivu }}=67, \mathrm{n}_{\text {Arali }}=44\right)$. Each species in the quadrate were identified, enumerated, and then recorded. The zonation pattern of each species was also examined along the transects $(10 \mathrm{~m}$ width) across the land-water margin.

\section{Environmental parameters}

Subsurface water samples were collected from the selected two sites at the points of the transects. A minimum of 3 samples were taken from each transect line and hence 57 samples altogether. The water temperature was recorded in the field using a standard degree centigrade thermometer. The water $\mathrm{pH}$ was measured with a digital $\mathrm{pH}$ probe (Voniry make, Model No. 8541957750), electric conductivity by laboratory Eh meter ((ECscan20 conductivity tester), dissolve oxygen with a digital DO meter (JPB-607A dissolved oxygen meter/ Analyzer), and salinity by a portable refracttometer (BIOBASE make, Model No. Bk-Pr32). 


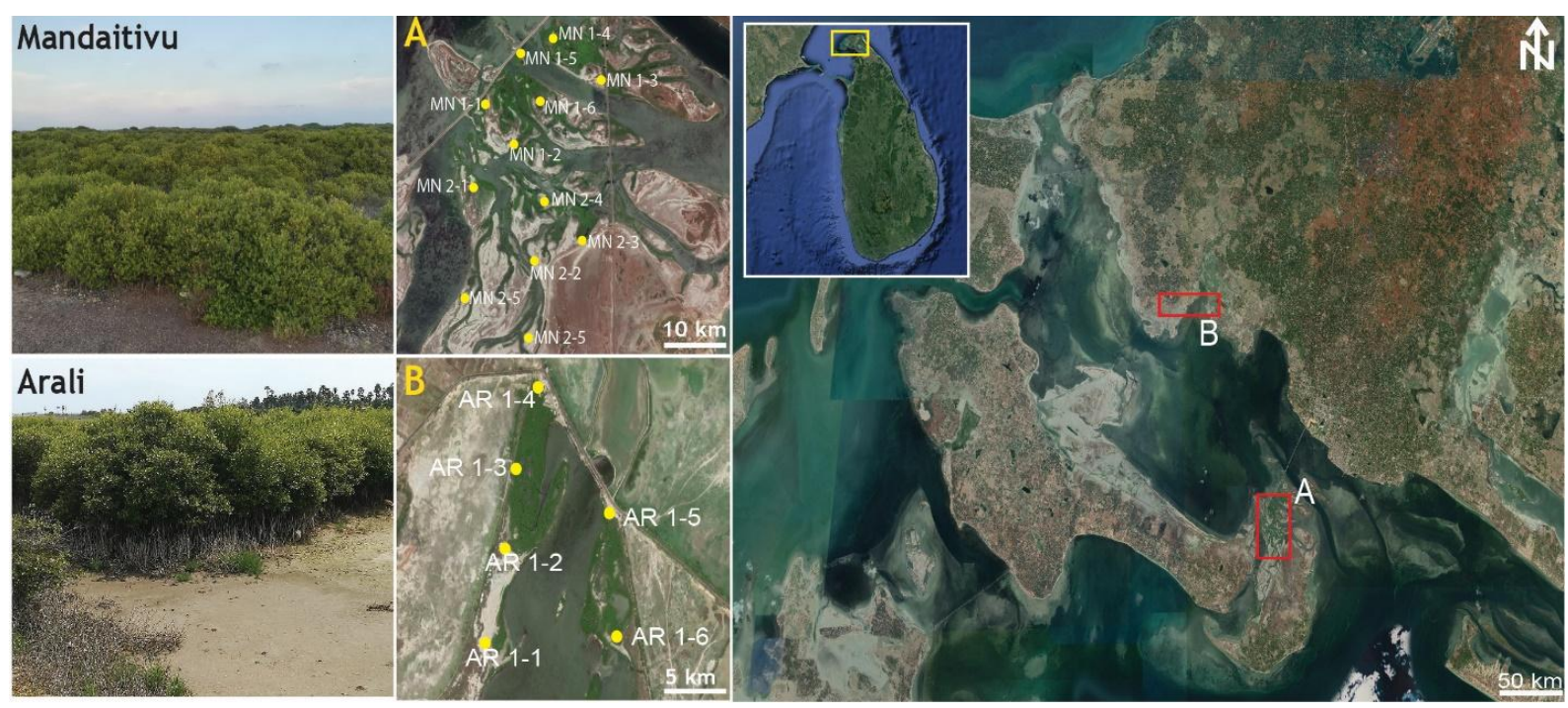

Figure 1: Map of the study area

Biodiversity of both mangrove stands was analyzed with the use of various indices including Shannon diversity (H'), Pielou's evenness (J'), Simpson's dominance index $\left(\lambda^{\prime}\right)$ (Peet, 1975) Margalef species richness (d') (Gamito, 2010). Total phylogenetic diversity index (sPhi+), taxonomic diversity $(\Delta)$, average taxonomic distinctness index $(\Delta+)$, and variation in taxonomic distinctness index $(\Lambda+)$ (S. Sreelekshmi, Nandan, Kaimal, Radhakrishnan, \& Suresh, 2020) were also calculated for comparing the biodiversity among sites. Cluster analysis and similarity percentage (SIMPER) were performed based on the BrayCurtis dissimilarity matrix. Apart from these indices niche width was also calculated (Levins, 1968). A multiple response permutation procedure was applied to check for significant differences between the clusters. Multi-Dimensional Scaling (MDS) and Principal Component Analysis (PCA) were performed to clarify the relationship of environmental factors on the plant community. Pearson's correlation coefficients were calculated to assess environmental parameters and stand characteristics. Community structure was analyzed with PRIMER v6 (Clarke \& Gorley, 2006)whilst other quantitative data were analyzed using SPSS 17.0.

\section{RESULTS AND DISCUSSION Species composition and distribution}

A sum of ten true-mangrove species representing six families were identified from the selected sites of Mandaitivu and Arali (Figure 2). Niche width measures the degree of specialization of a species and its ability to exploit an environmental range in space and also to maintain its population in different environments ( $\mathrm{S}$. Sreelekshmi et al., 2020). The species with wider niches can be considered as generalists (utilize a wide range of resources) and narrow niche as specialists, exploit a specific set of resources (Smith, 1992). The highest niche width was exhibited by Bruguiera cylindrica (2.99) followed by Lumnitzera racemosa (2.86), Excoecaria agallocha (2.75), and Avicennia marina (2.74) which reveals their capability to adapt to the environmental conditions in Mandaitivu and Arali (Table 1). However, Aegiceras corniculatum (1.88), Bruguiera gymnorrhiza (1.91) and Acanthus ilicifolius (1.92) have shown narrow niche width, were found restricted to few parts of the area sampled. Highest density over the sites sampled was exhibited by Avicennia marina (653) followed by Luminetzera racemosa (578) and Excoecaria agallocha (507). Amongst these, Avicennia marina has extensively dominated over the sites sampled. Whilst lower density have been shown by Pemphis acidula (17). 


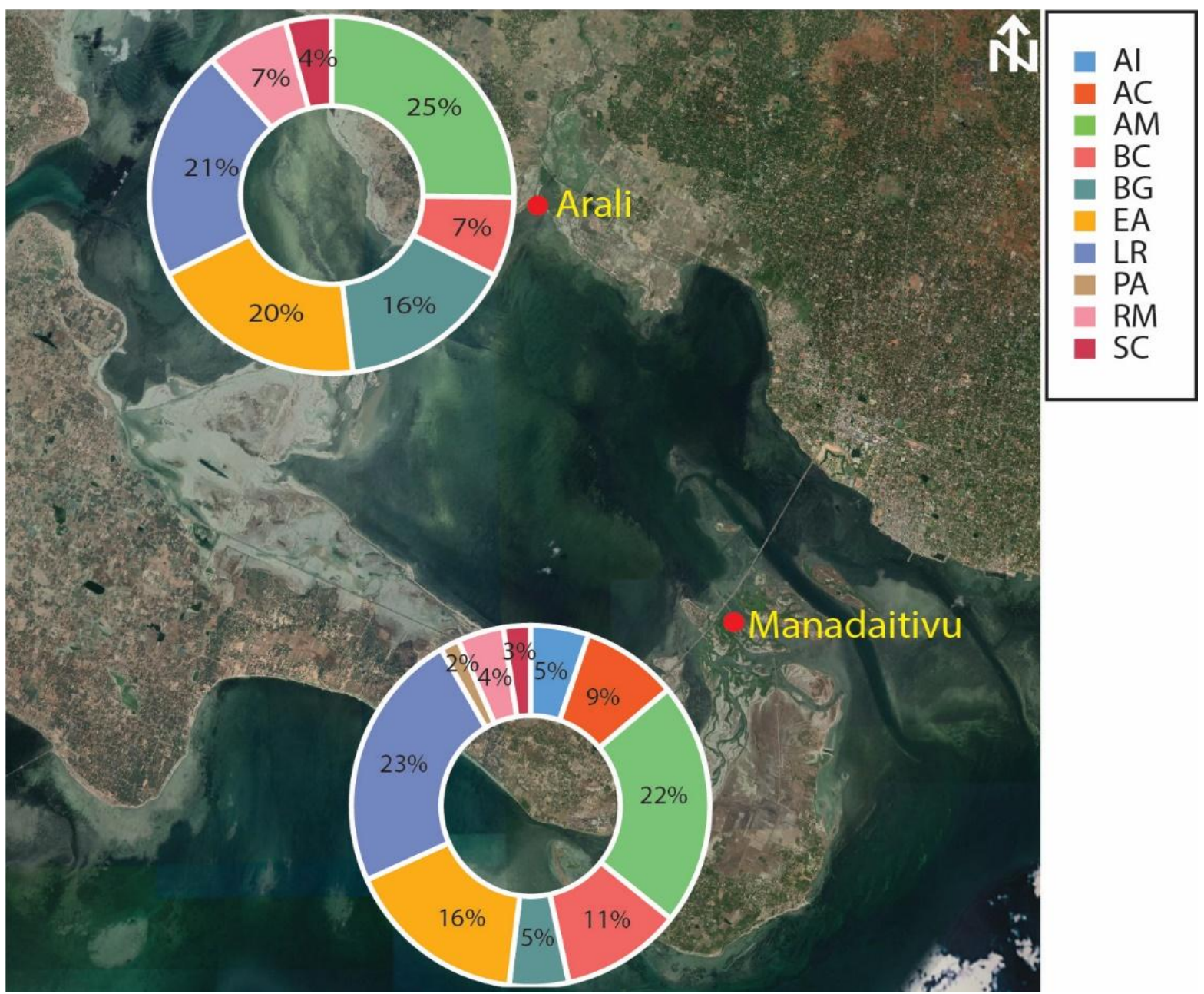

Figure 2: Species composition in the selected sites (AI: Acanthus ilicifolius, AC: Aegiceras corniculatum, AM: Avicennia marina, BC: Bruguiera cylindrica, BG: Bruguiera gymnorrhiza, EA: Excoecaria agallocha, LR: Lumnitzera racemosa, PA: Pemphis acidula, RM: Rhizophora mucronata, SC: Sonneratia caseolaris).

\section{Diversity analysis}

The Shannon diversity Index for Mandaitivu and Arali was 2.02 and 1.79 respectively whereas Simpson index for Mandaitivu and Arali was 0.84 and 0.82 respectively. Shannon diversity ranged from 1.79 to 2.02 with the highest species richness exhibited in Mandaitivu. (2.02). However, the

Table 1: Forest structural indices of true mangrove flora from Mandaitivu and Arali

\begin{tabular}{|c|c|c|c|c|c|c|c|c|c|c|}
\hline & $\mathbf{S}$ & $\mathbf{N}$ & d & $\mathbf{J}^{\prime}$ & $\mathbf{H}^{\prime}$ & 1-Lamda & $\Delta$ & $\Delta+$ & $\lambda+$ & sPhi+ \\
\hline andaitivu & 10 & 14426 & 0.94 & 0.88 & 2.02 & 0.84 & 83.69 & 99.27 & 54.32 & 950 \\
\hline Arali & 7 & 23990 & 0.594 & 0.92 & 1.79 & 0.82 & 80.62 & 98.62 & 113.38 & 650 \\
\hline
\end{tabular}

S-Total species, N-Total individuals, d- Species richness (Margalef), J'-Pielou's evenness, H'-Shannon, 1Lambda- Simpson, $\Delta$ - Taxonomic diversity, $\Delta+$ - Average taxonomic distinctness index, $\lambda+-$ Variation in taxonomic distinctness index, $\mathrm{sPhi}+$ - Total phylogenetic diversity index. 


\section{Environmental parameters}

Water quality parameters displayed a tidal fluctuation along with the least freshwater input and increased evaporation(Bastiaanssen \& Chandrapala, 2003) in these regions. This has resulted in an extremely high salinity and lower dissolved oxygen (Table 3). Salinity ranges between 25 and $27 \mathrm{ppt}$ whilst $\mathrm{pH}$ showed a slight alkalinity with a variation from $7.05(+0.19)$ to $7.4(+0.1)$. The soil water content varied between 24 and $26 \%$ showing acritical dryness of the region sampled.

Spatial variability: Mandaitivu versus Arali
Relatively higher species diversity and abundance have been noted in Mandaitivu $\left(H^{\prime}=2.02\right)$ than Arali $\left(H^{\prime}=1.79\right)$ (Table 2). A sum of ten species have been recorded from Mandaitivu whereas seven species were recorded from Arali. Yet it could be observed that the evenness in Arali $\left(\mathrm{J}^{\prime}=0.92\right)$ is quite higher than that of Mandaitivu $\left(\mathrm{J}^{\prime}=0.88\right)$. Avicennia marina, Lumnitzera racemosa, and Excoecaria agallocha were predominantly observed in both sites at large numbers. However, rare occurrences of Acanthus ilicifolius, Aegiceras corniculatum and Pemphis acidula recorded in Mandaitivu were not observed in Arali.

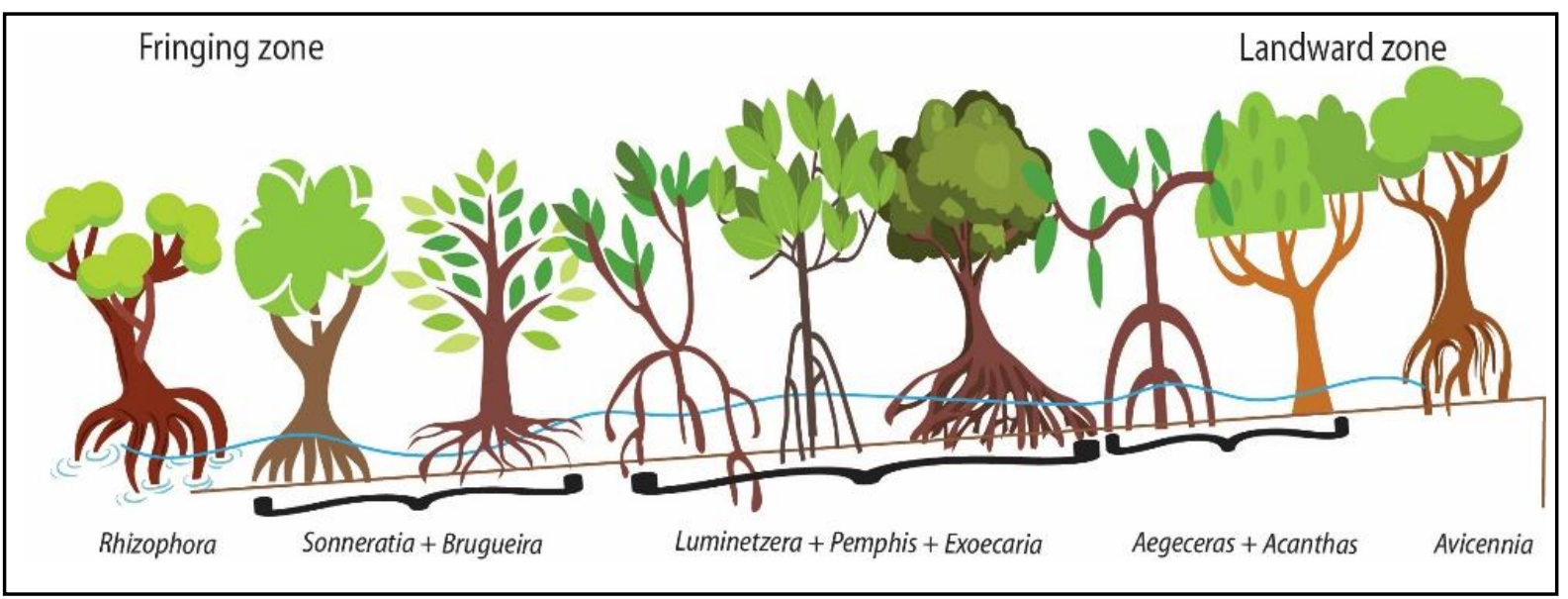

Figure 3: Zonation pattern of mangroves in Mandaitivu

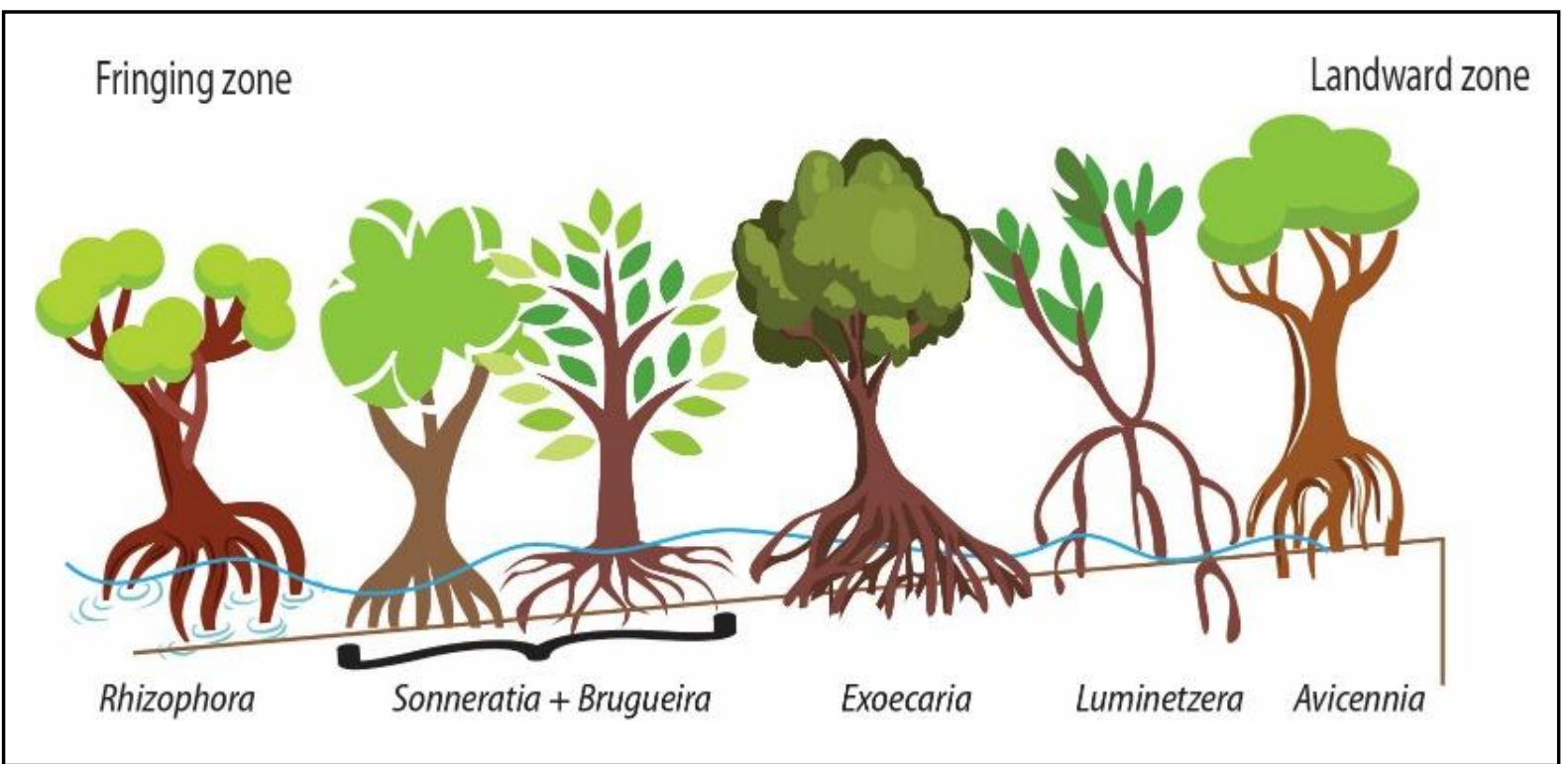

Figure 4: Zonation pattern of mangroves in Arali

\section{Zonation pattern}

It was not easy enough to observe a clear zonation pattern in the areas selected for the mangrove survey. Yet with the available data, a rough representation of the zonation pattern has been created. Zonation in both areas consisted of 
Rhizophora in the fringing zone and Avicennia in the landward zone. In Mandaitivu, Sonneratia and Brugueira was observed in the mixed zone towards fringing zone whilst Luminetzera, $P$. acidula, and Exoecaria were in another mixed group landwards (Figure 3). Aegiceras and Acanthus were observed toward the land zone. In Arali, a similar mixed zone was observed comprising of Sonneratia and Brugueira toward the fringing zone (Figure 4). However, singular zones of Exoecaria and Luminetzera were observed landward.

\section{Cluster analysis and community structure}

Form the species cluster analyses (Bray-Curtis similarity: $80 \%$ ) and multidimensional scaling plots based on mangrove abundance and salinity in both sites; Mandaitivu was classified into three clusters; Table 2: Environmental parameters in the surveyed site the first cluster included $A$. corniculatum, $A$. ilicifolius, Brugueira spp. whilst L. racemosa, A. marina and $E$. agallochawere observed on the second cluster. S. caseolaris, R. mucronata and $P$. acidulawere included in the third cluster (Figure 5). On contrary, species composition in Arali were categorized into two clusters where $R$. mucronata, $B$. cylindrica and $S$. caseolaris included in the first cluster while $L$. racemosa, A. marina and $E$. agallocha $B$. gymnorrhiza were encompassed into the second cluster. On the other hand, 2D MultiDimensional Scaling plots have revealed that the similarity of the sites sampled in Mandaitivu comprised more than $80 \%$ except for $P$. acidula whereas all the species recorded in Arali showed more than $80 \%$ resemblance (Figure 5).

\begin{tabular}{|l|r|r|r|r|}
\hline \multirow{2}{*}{} & \multicolumn{2}{|c|}{ Mandaitivu } & \multicolumn{2}{c|}{ Arali } \\
\cline { 2 - 5 } & Mean & \multicolumn{1}{|c|}{ SE } & Mean & \multicolumn{1}{c|}{ SE } \\
\hline Salinity $(\mathrm{ppt})$ & 26.67 & 0.89 & 27.58 & 0.95 \\
\hline $\mathrm{pH}$ & 7.05 & 0.19 & 7.4 & 0.1 \\
\hline Conductivity $\left(\mu \mathrm{S}^{-1}\right)$ & 784.17 & 48.44 & 873 & 27.69 \\
\hline Elevation & 7.97 & 0.1 & 8.06 & 0.07 \\
\hline Soil water content (\%) & 23.84 & 0.95 & 26.29 & 0.65 \\
\hline DO $(\mathrm{ppm})$ & 6.24 & 0.28 & 6.85 & 0.24 \\
\hline Tidal inundation $(\mathrm{m})$ & 0.16 & 0.04 & 0.15 & 0.03 \\
\hline Sediment type & \multicolumn{3}{|c}{ Clayey sand } & Clay \\
\hline
\end{tabular}

SE- Standard error

\section{Environment-plant interactions}

Amidst the several environmental parameters checked mangrove abundance showed a positive correlation (Pearson) with salinity and electric conductivity. A highly significant positive correlation was observed between salinity and mangrove abundance and salinity $(0.969, \mathrm{p}=0.000$ in Mandaitivu and 0.938, $\mathrm{p}=0.002$ in Arali) whilst electric conductivity had a fairly strong correlation (0.669, $\mathrm{p}=0.017$ in Mandaitivu and 0.663, $\mathrm{p}=0.105$ in Arali). However, positive but weak correlation between $\mathrm{pH}$ and tidal amplitude in both sites.

Principal Component Analysis (PCA) of Mandaitivu revealed a strong impact of salinity, tidal amplitude, $\mathrm{pH}$, and electric conductivity on the sampling points. At the same time, PCA in Arali revealed such an influence is strongly given by salinity, tidal amplitude, and conductivity. Hence, this study suggests, that salinity, tidal amplitude, and electric conductivity, and $\mathrm{pH}$ are the key factors swaying the mangrove vegetation and community structure (Figure 6).

\section{Species composition}

Altogether ten mangrove species have been identified from the selected sites of Mandaitivu and Arali. It should be noted that there have not been any previous studies reported in this study area thus this paper contributes to report the floral diversity for the very first time. For the past 30 years, the northern parts of Sri Lanka were not accessible due to the civil war conditions that prevailed in the country. The areas were allowed for survey only after the end of the war by 2009. However, there is a lack of enthusiasm in many researchers in accessing the areas for research purposes and study the mangrove ecology.

Of the ten species reported at the respective site, the mangrove forest is typically dominated by Avicennia marina, Luminetzera racemosa, and Excoecaria agallocha representing a 'high saline' 
mangrove ecosystem. Noteworthy domination has been observed in Arali by A. marina (25\%) even though the species diversity is reported low there. Nevertheless, past studies taken in other Sri Lankan dry zone forests have revealed that $A$. marina has a resistance towards extreme environmental conditions thus have a tendency to be widespread throughout the country's mangrove ecosystems (Arulnayagam, 2020; Subasinghe, 2015; Prasanna, Ranawana, \& Jayasuriya, 2019; Ellepola \& Ranawana, 2015).
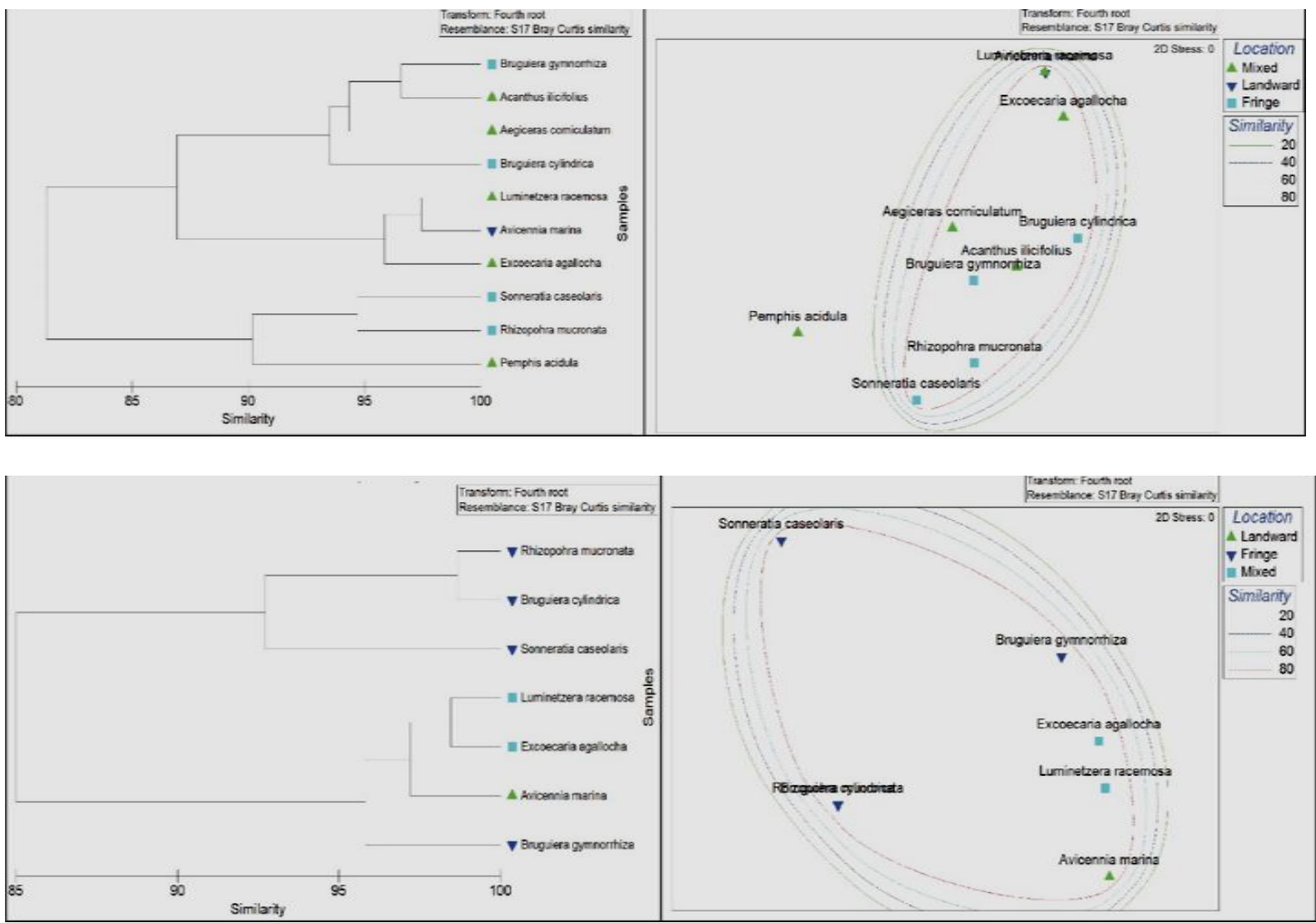

Figure 5: Cluster analysis and 2D- Multi-Dimensional Scaling of Community structure in (a) Mandaitivu and (b) Arali.

\section{Diversity analysis and community structure}

High Shannon index means there is a more amiable environment that facilitates abundance due to the presence of a larger number of species or uniform distribution of several species in a quadrat (Suseela Sreelekshmi et al., 2018). Hence, the mangrove forests in both sites looked healthy status, in terms of Shannon index since it was near two (2). In contrast, Simpson index was observed lower as
$<1$ in both sites surveyed. $\beta$ diversity value was found to be 3 which is as much as low, indicating a high homogeneity of mangrove species between the two mangrove forests in Mandaitivu and Arali. Figure 5 represents the Cluster analysis and 2D Multi-Dimensional Scaling (MDS) on an unambiguous scale in Mandaitivu and Arali, respectively. 

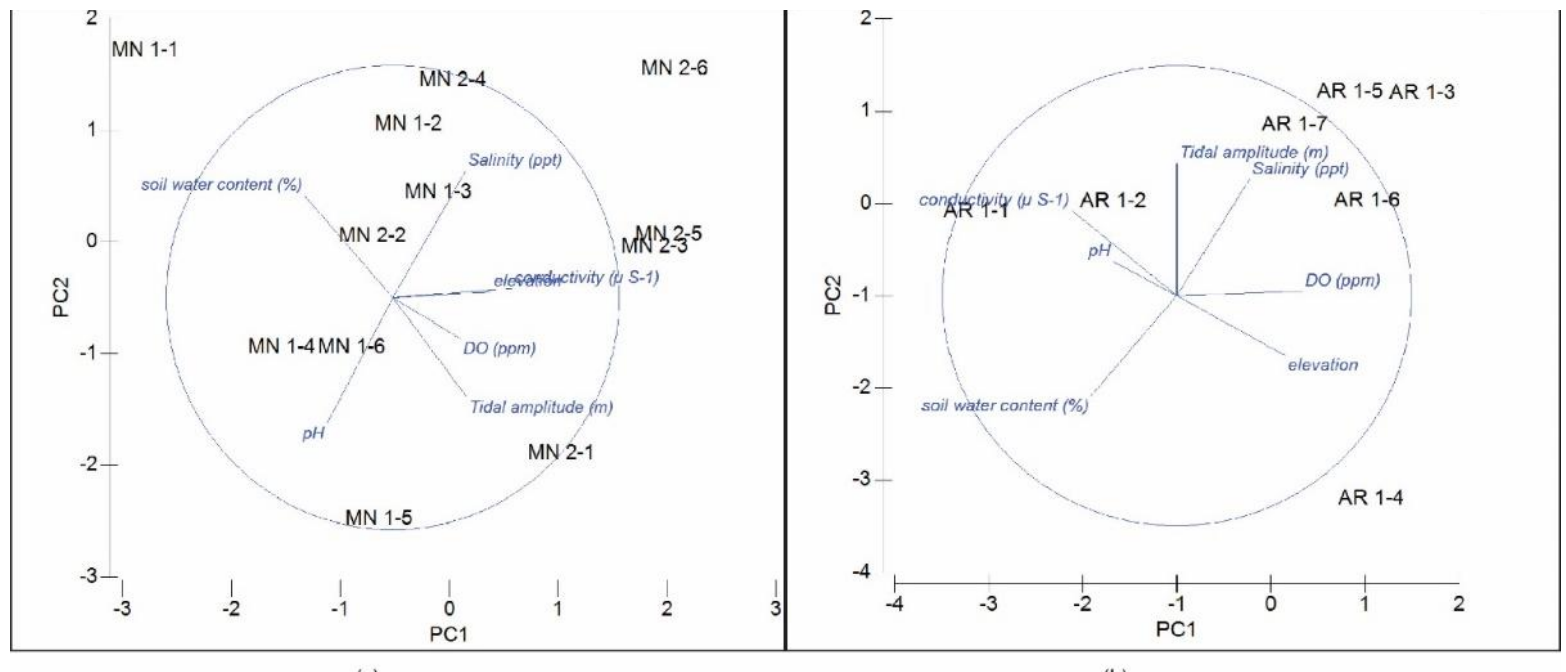

(a)

(b)

Figure 6: Principal Component Analysis (PCA) depicting the influence of environmental factors over the sites sampled in (a) Mandaitivu and (b) Arali.

\section{Zonation pattern}

Mangrove species respond to various tidal regimes, where they occupy a convenient space on the mangrove forest, which forms a distinct zone of unique species. Yet the low tidal amplitude in the seas around Sri Lanka and the coastal geomorphology restricts the inter-tidal zone into narrow strips (Amarasinghe \& Perera, 2017). Generally, A. marina could survive very high salinities yet are more common around the Sri Lankan mangrove forests, especially in the dry zones. Silva \& Silva, 1998, specifically refers to such a type of mangroves as 'high saline' and they occupy the river estuaries typically in the dry zones.

\section{Environment - plant relations}

Long-term monitoring data of hydro-graphic parameters and temperature in Jaffna region have shown year-round mean temperature over $24^{\circ} \mathrm{C}$ and the hottest months are observed during May - July, whilst peak rainfall could be observed throughout October, November, and December (Figure 7). This makes Jaffna a dry zone and gives a reason for the increased salinity observed throughout the sites surveyed. In addition, the seas around Sri Lanka are micro-tidal and semi-diurnal in which rise and fall is between $0.7 \mathrm{~m}$ and 0.05 , spring and neap tides respectively. Especially the influence of tides is less in the northern parts of the country (Wijeratne \& Pattiaratchi, 2003). Hence, logical evidences lack to analyze the role of environmental factors excluding salinity to have a prominent influence over the mangrove distribution and zonation observed in the sites surveyed, even though PCA analyses show a promising result.
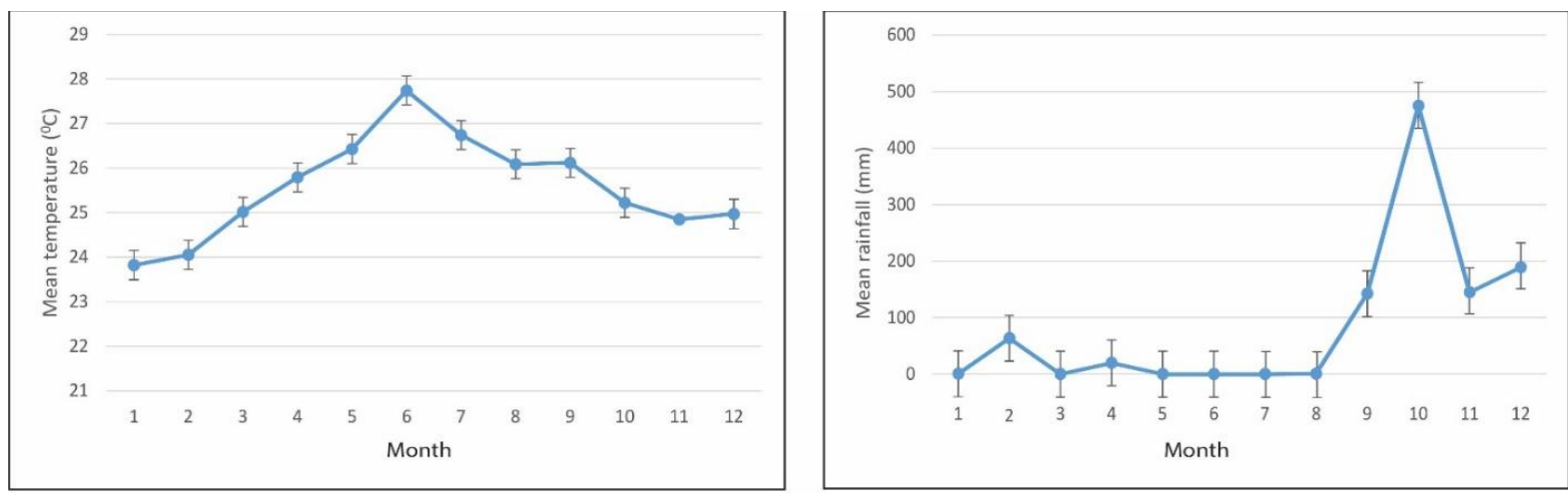

Figure 7: Summary of hydrographic factors from a long-term monitoring record (Source: Meteorological Department of Sri Lanka). 


\section{CONCLUSION}

The assessment of the forest composition and structure of Mandaitivu and Arali have revealed a sum of ten true mangrove species, distributed throughout the estuarine areas, occurring inhomogeneous and intricate mixtures with the dominance of by Avicennia marina, Luminetzera racemosa, and Excoecaria agallocha representing a 'high saline' mangrove ecosystem. Even though proper structural development has not been observed in the mangrove forests, they tend to show a zonation involving Rhizophora in the waterfront and Avicennia towards the landward margin. Mangrove strands showed a significant correlation with the edaphic factors, especially with salinity, conductivity, tidal regime, and $\mathrm{pH}$. Lack of knowledge and awareness and negligence has resulted in poor management and degradation of these mangrove forests in the Northern Province of Sri Lanka. Further research and knowledge development are recommended in these and adjacent areas for the productivity, dynamics, and sustainability of the mangrove forests.

\section{Acknowledgment}

The author is grateful to the Regional Agrarian Research and Development Center, Kilinochchi, Sri Lanka for their contribution to laboratory analysis. The Meteorological Department of Sri Lanka provided the data on some edaphic factors. In addition, I thank Kirushnathasan Suresh for assisting in field surveys and samplings.

\section{REFERENCES}

Amarasinghe, M. D., \& Perera, K. A. R. S. (2017). Ecological biogeography of mangroves in Sri Lanka. Ceylon Journal of Science, 46(5), 119. https://doi.org/10.4038/cjs.v46i5.7459

Arulnayagam, A. (2020). Floral distribution , abundance and diversity of mangroves in Sangupiddy, Kilinochchi, the northern coast of Sri Lanka. 01(01), 21-27.

Bastiaanssen, W. G. M., \& Chandrapala, L. (2003). Water balance variability across Sri Lanka for assessing agricultural and environmental water use. Agricultural Water Management, 58(2), 171-192.

https://doi.org/10.1016/S0378-

3774(02)00128-2

Clarke, K. R., \& Gorley, R. N. (2006). PRIMER v6:
User Manual/Tutorial (Plymouth Routines in Multivariate Ecological Research). PRIMER-E.

Duke, N. C. (1992). Mangrove floristics and biogeography. (January 1992), 63-100. https://doi.org/10.1029/ce041p0063

Ellepola, G., \& Ranawana, K. B. (2015). Panama Lagoon: A unique mangrove ecosystem in the east coast of Sri Lanka. Wetlands Sri Lanka, 2(1), 10-19.

Gamito, S. (2010). Caution is needed when applying Margalef diversity index. Ecological Indicators, 10(2), 550-551. https://doi.org/10.1016/j.ecolind.2009.07.006

Gopalakrishnan, T., Kumar, L., \& Mikunthan, T. (2020). Assessment of spatial and temporal trend of groundwater salinity in Jaffna Peninsula and its link to paddy land abandonment. Sustainability (Switzerland), 12(9). https://doi.org/10.3390/su12093681

Jayatissa, L. P., Dahdouh-Guebas, \& Koedam, N. (2002). A review of the floral composition and distribution of mangroves in Sri Lanka. Botanical Journal of the Linnean Society, 138(1), 29-43.

https://doi.org/10.1046/j.10958339.2002.00002.x

K.B. Ranawana. (2017). Mangroves of Sri Lanka. 368.

Karunathilake, K. M. B. C. (2003). Status of Mangroves in Sri Lanka. Journal of Coastal Development, 7(1), 5-9. Retrieved from https://www.omicsonline.com/openaccess/status-of-mangroves-in-sri-lanka1410-5217-7-156.pdf

Levins, R. (1968). Evolution in Changing Environments. Science, 167(3924), 14781480.

Peet, R. K. (1975). Relative Diversity Indices. 56(2), 496-498.

Prasanna, M. G. M., Ranawana, K. B., \& Jayasuriya, K. M. G. G. (2019). Species composition, abundance and diversity of mangroves in selected sites in Amprara District in the east coast of Sri Lanka. Ceylon Journal of Science, 48(2), 169. https://doi.org/10.4038/cjs.v48i2.7621

Rotich, B., Mwangi, E., \& Lawry, S. (2016). Where Land Meets the Sea: Governance and tenure. 
Bogor, Indonesia: CIFOR; Washington, DC: USAID Tenure and Global Climate Change Program. This, (December).

Silva, M. De, \& Silva, P. K. De. (1998). Status, diversity and conservation of the mangrove forests of Sri Lanka. Journal of South Asian Natural History, 3(1), 79-102.

Sippo, J. Z., Lovelock, C. E., Santos, I. R., Sanders, C. J., \& Maher, D. T. (2018). Mangrove mortality in a changing climate: An overview. Estuarine, Coastal and Shelf Science, 215(October), 241-249. https://doi.org/10.1016/j.ecss.2018.10.011

Smith, T. J. (1992). Forest structure. 41, 101-136. https://doi.org/10.1029/ce041p0101

Snedaker, S. C. (1986). The mangrove ecosystem: Research methods (Vol. 25). https://doi.org/10.1016/0304-3770(86)90046$\mathrm{x}$

Sreelekshmi, S., Nandan, S. B., Kaimal, S. V., Radhakrishnan, C. K., \& Suresh, V. R. (2020). Mangrove species diversity, stand structure and zonation pattern in relation to environmental factors - A case study at Sundarban delta, east coast of India.

Regional Studies in Marine Science, 35, 101111. https://doi.org/10.1016/j.rsma.2020.101111

Sreelekshmi, Suseela, Preethy, C. M., Varghese, R., Joseph, P., Asha, C. V., Bijoy Nandan, S., \& Radhakrishnan, C. K. (2018). Diversity, stand structure, and zonation pattern of mangroves in southwest coast of India. Journal of Asia-Pacific Biodiversity, 11(4), 573-582. https://doi.org/10.1016/j.japb.2018.08.001

Subasinghe, U. (2015). Floral diversity of six mangrove forests along the northwestern coastline of wet, intermediate and dry climate zones of Sri Lanka. Wildlanka, 3(4), 184-194.

Wijeratne, E. M. S., \& Pattiaratchi, C. B. (2003). Sea Level Variability in Sri Lanka Waters. 15. Retrieved from http://wcrp.ipsl.jussieu.fr/Workshops/SeaLev el/Posters/2_1_WijeratneRevised.pdf 